ORIGINAL ARTICLE

\title{
Health of children working in small urban industrial shops
}

\author{
I A Nuwayhid, J Usta, M Makarem, A Khudr, A El-Zein
}

Occup Environ Med 2005;62:86-94. doi: 10.1136/oem.2004.015503

See end of article for authors' affiliations

....................

Correspondence to: Prof. I A Nuwayhid, Department of

Environmental Health,

Faculty of Health Sciences,

American University of

Beirut, Lebanon;

nuwayhid@aub.edu.1b

Accepted 7 June 2004

\begin{abstract}
Aims: To explore associations between work status and multidimensional health indices in a sample of urban Lebanese children.

Methods: A cross-sectional survey was used to compare 78 male children (aged 10-17 years) working full time in small industrial shops, and a comparison group of 60 non-working male schoolchildren. All children lived and worked or studied in the poor neighbourhoods of three main Lebanese cities.

Results: Working children reported frequent abuses. They smoked and dated more than the comparison group. They also reported a higher number of injuries (last 12 months) and recent skin, eye, and ear complaints (last two weeks). Physical examination revealed more changes in their skin and nails, but no differences in height or weight compared to non-working group. A higher blood lead concentration was detected among working children, but no differences in haemoglobin and ferritin. No differences were noted between the two groups of children regarding anxiety, hopelessness, and self-esteem. The drawings of the working children, however, revealed a higher tendency to place themselves outside home and a wider deficit in developmental age when compared to non-working children.

Conclusion: Significant differences were found between working and non-working children with respect to physical and social health parameters, but differences were less with regard to mental health. Future research should focus on (1) more sensitive and early predictors of health effects, and (2) long term health effects. The generality of findings to other work settings in the developing world should also be tested.
\end{abstract}

$M$ ore than 200 million children less than 14 years of age work worldwide, many of whom are employed in hazardous occupations and are doing the same type of work as adults. ${ }^{1}$ Children's increased vulnerability puts them at a high risk of work related health problems. ${ }^{2}{ }^{3}$ Nevertheless, the health of working children is still an under-researched topic, ${ }^{4}$ probably because child labour in its harshest forms is mostly limited to developing countries. Most of the published research from more developed countries reports a high rate of work related injuries among children working in agricultural work and retail services, including fast-food chains. ${ }^{356}$

Child labour in Lebanon, a small service oriented country, may be less devastating than in other developing countries. A national survey reported that $1.8 \%$ of the $10-14$ year old children and $11.3 \%$ of those aged $15-18$ years work. ${ }^{7}$ However, child labour in Lebanon is not equally distributed, but clearly associated with the poor outskirts of cities and the underdeveloped peripheral regions of the country. ${ }^{7}$ The national survey also revealed that the preponderance of child labourers are boys who are employed in small industrial shops. ${ }^{7}$

The present study is motivated by prior research in Lebanon which revealed the general inadequacy of health and safety conditions at work, ${ }^{8}$ and the limited access of children to health care in poor neighbourhoods. The study examines associations between multidimensional indices of health (physical, social-emotional, mental) and child labour in Lebanon, by comparing children working in small industrial shops with non-working children. We hypothesised that working children will be disadvantaged in all health dimensions.

\section{METHODS}

\section{Study population}

The study population was limited to 10-17 year old boys living in urban areas and working in a variety of small industrial shops (for example, mechanics, carpentry, autobody repair, spray painting). Several districts within the cities of Tripoli (north of Lebanon), Saida (south of Lebanon), and Beirut (the capital) were purposively targeted because of the presence of clusters of small industrial shops, and a high proportion of working children.

\section{Study sample}

Terre des Hommes, an international non-governmental organisation (in collaboration with UNICEF and the Lebanese Ministry of Education) manages vocational and social programmes for working and non-working children in the study areas. The programmes mainly target children working in jobs assumed to be more hazardous to safety and health. The organisation provided a list of all working children enrolled in the training programme, together with information on age, sex, and type of work performed. Children's participation in the vocational programme was conditional on parents' or guardians' approval. All 10-17 year old boys employed in industrial shops were identified. The families of eligible children were contacted in person, and informed consent was conducted for participation in the study. All identified working children participated in the study. A comparison group of children of the same age group was recruited from students attending schools in the same areas. Schoolchildren in the comparison group were informed of the study through their schools or the social programme. School administrators also helped in securing the approval of the parents/guardians. The comparison group was a volunteer convenience sample, and response rate could not be computed.

Children were invited to present at a specified time and date to the vocational centre of their area of residence. Those who so presented were again informed of the study and asked to write or sign their name on an informed consent form. Subjects were then interviewed by trained first year medical students and examined by one of two senior family

Abbreviations: $\mathrm{Cl}$, confidence interval; $\mathrm{Hb}$, haemoglobin; LL, Lebanese pounds; $\mathrm{OR}$, odds ratio; $\mathrm{Pb}-\mathrm{B}$, blood lead concentration 


\section{Main messages}

- Children working in urban industrial shops are socially disadvantaged.

- Working and non-working children had significant differences in physical and social health parameters, but less in mental health.

- Working in small industrial shops predisposes the child to unhealthy lifestyles.

- The non-working children most probably perceive themselves as temporary students who will soon join the labour force.

physicians, who also drew blood samples. Monetary compensation was given to all participating children to cover transportation and one day's work equivalence.

\section{Data collection}

All interviews and examinations were conducted in 1997, following approval by a national committee on child labour, under the Ministry of Social Affairs. Separate stations for general interview, mental health assessment, physical examination, and blood drawing were set in each centre. Children rotated between the different stations in any order. Except for those at the general interview station, all interviewers and the physicians were blinded to the work status of the child.

\section{General interview}

A standardised questionnaire was used that inquired about the sociodemographic background of the child, his schooling, nutrition (intake of fruit, vegetables, milk, caffeine), social habits (smoking, alcohol intake, dating), acute and chronic health problems, and use of health services. Working children were asked about their workplace, employer, and the use of their salaries.

\section{Mental health assessment}

Mental health was assessed using three validated questionnaires translated into Arabic: the Children's Manifest Anxiety Questionnaire, ${ }^{10}$ the Hopelessness Scale, ${ }^{11}$ and the SelfEsteem Inventory. ${ }^{12}$ The first two were translated and back translated before a final version was used in this study, while the third was already used in Arabic.

The Children's Manifest Anxiety Questionnaire ${ }^{9}{ }^{10}$ includes 37 questions -28 anxiety items and 9 lie items, to which the child answers by either yes or no. The construct, content, and criterion related validity of the scale are well established. ${ }^{13}$ It has a reliability of around 0.83 and can be used readily at grade 3 or above. ${ }^{10}$ A higher score (maximum 28) indicates higher anxiety.

The Hopelessness Scale for Children ${ }^{11}$ includes 17 items, to each of which the child has to indicate if it is true or not (internal consistency 0.75, p $<0.001$ ). Test-retest reliability and concurrent validity are established..$^{14}$ Performance on this scale is negatively correlated with self-esteem and positively correlated with depression. ${ }^{11}$ The readability of the items corresponded to an upper first or lower second grade level. A higher score (maximum 17) indicates greater hopelessness or "negative expectancies for the future". ${ }^{11}$

The Self-Esteem Inventory ${ }^{12}$ consisted of 29 statements to which the child had to answer yes or no. A higher score (maximum 29) indicates a higher self-esteem. This is a shorter form of an original 50 item scale, with a test-retest reliability of 0.88 over five weeks, ${ }^{12}$ and a well established convergent and discriminant validity. ${ }^{15}$

\section{Policy implications}

- Health and safety conditions at work should be improved, and physical and mental health of working children routinely evaluated.

- Awareness campaigns to reduce exposure of working children to risky social behaviours should be initiated.

- There should be control of school dropouts and provision of properly supervised technical training for children who elect to leave school.

For each of the three scales, mean scores with standard deviation (SD) were computed. Scores were also grouped into four quartiles, using cut-off points determined for the whole study sample.

Children were also provided with a white sheet of paper and a pencil and were asked to draw themselves inside their homes. One of the authors (JU), who was blinded to the status of the child, scored each drawing based on the children's drawing code book. ${ }^{16}$ Each drawing was scored for complexity or richness of drawing (low, average, high) and for general impression (negative, average, positive). Developmental age was estimated for each drawing based on Good Enough Harris scoring. ${ }^{17}$ The difference between the actual chronological age and the estimated developmental age was computed for each child. In addition, a note was made when the child drew himself outside the house. Inter-rater agreement was determined for two raters (co-authors JU and MM) who scored all drawings. Identical scores were given in $78 \%$ of the drawings for general impression (kappa 0.29), 79\% for complexity (kappa 0.57 ), 76\% for mental age within one year (correlation 0.58), and 91\% for location of child inside or outside home (kappa 0.83 ). The principal coder's reliability over four weeks was 0.42 for general impression, 0.53 for complexity, 0.69 for mental age, and 0.82 for location of child.

Lower complexity, a negative general impression, selfrepresentation outside the house, and a wider difference between the chronological and developmental ages were indicators of a less advantaged mental health status.

\section{Physical examination}

Children were asked to take their shoes off. Their height and weight were measured on a mechanical scale. Visual acuity was tested using a Snellen chart posted on a wall at a 6 feet distance. The child was asked to sit on a chair and relax for a few minutes before his blood pressure was measured. A full physical examination was then conducted assessing gait, posture, nails, hands, arms, legs, and feet. Eyes, ears, nose, mouth, and throat were checked in addition to chest auscultation.

\section{Blood samples}

Blood was tested for haemoglobin $(\mathrm{Hb})$, ferritin, and lead concentration $(\mathrm{Pb}-\mathrm{B})$. The blood lead samples were mailed to the University of Newcastle upon Tyne for analysis in an accredited laboratory at the Department of Environmental and Occupational Medicine. The other tests were performed in a hospital based clinical lab in Beirut. Mean $\mathrm{Hb}(\mathrm{g} / \mathrm{l})$, ferritin $(\mu \mathrm{g} / \mathrm{l})$, and blood lead concentration $(\mu \mathrm{g} / \mathrm{dl})$ were reported. $\mathrm{Pb}-\mathrm{B}$ was further divided into four categories $(<10$, $10-14,15-19$, and $\geqslant 20 \mu \mathrm{g} / \mathrm{dl}$ ), with $10 \mu \mathrm{g} / \mathrm{dl}$ being the CDC permissible level for children. ${ }^{18}$

\section{Data management and statistical analysis}

The work characteristics of the working children were described. Their sociodemographic characteristics, social 


\begin{tabular}{|c|c|c|}
\hline & $n$ & $\%(95 \% \mathrm{Cl})$ \\
\hline \multicolumn{3}{|l|}{ Work experience } \\
\hline Current workplace* & $\mathrm{n}=77$ & \\
\hline Carpentry & 19 & 24.7 (16.6 to 35.8$)$ \\
\hline Mechanics & 22 & 28.6 (18.8 to 40.0$)$ \\
\hline Metal works & 27 & 35.1 (24.5 to 46.8$)$ \\
\hline Other & 9 & $11.7(5.5$ to 21.0$)$ \\
\hline Years in current workplace & $n=76$ & \\
\hline$<1$ & 13 & $17.1(9.4$ to 27.5$)$ \\
\hline 1 & 29 & $38.2(27.2$ to 50.0$)$ \\
\hline 2 & 15 & $19.7(11.5$ to 30.5$)$ \\
\hline$\geqslant 3$ & 19 & $25.0(15.8$ to 36.3$)$ \\
\hline Mean (SD) & $1.72(1.28)$ & \\
\hline Years ever worked & $\mathrm{n}=76$ & \\
\hline$<2$ & 33 & 43.4 (32.1 to 55.3$)$ \\
\hline 2 & 18 & $23.7(14.7$ to 34.8$)$ \\
\hline$\geqslant 3$ & 25 & $32.9(22.5$ to 44.6$)$ \\
\hline Mean (SD) & $2.34(1.89)$ & \\
\hline \multicolumn{3}{|l|}{ Salary } \\
\hline Weekly salary (Lebanese pounds $†$ ) & $n=76$ & \\
\hline$\leqslant 20000$ & 32 & 42.1 (30.9 to 54.0$)$ \\
\hline $21000-40000$ & 30 & 39.5 (28.4 to 51.4$)$ \\
\hline$>40000$ & 14 & $18.4(10.5$ to 29.0$)$ \\
\hline Proportion kept by child (\%) & $n=61$ & \\
\hline$\leqslant 33$ & 31 & $50.8(37.7$ to 63.9$)$ \\
\hline $34-66$ & 28 & 45.9 (33.1 to 59.2$)$ \\
\hline$>66$ & 2 & $3.3(0.4$ to 11.3$)$ \\
\hline Use of salary & $n=73$ & \\
\hline Family basic needsł & 47 & 64.4 (52.3 to 75.3$)$ \\
\hline Amusement & 11 & $15.1(7.8$ to 25.4$)$ \\
\hline Combination of above & 15 & 20.5 (12.0 to 31.6$)$ \\
\hline \multicolumn{3}{|l|}{ Work perceptions } \\
\hline Perception of physical exertion at work & $\mathrm{n}=77$ & \\
\hline Very tiring & 14 & $18.2(10.3$ to 28.6$)$ \\
\hline Difficult & 23 & $29.9(20.0$ to 41.4$)$ \\
\hline Easy/comfortable & 40 & $51.9(40.3$ to 63.5$)$ \\
\hline Preferences regarding current job & $\mathrm{n}=77$ & \\
\hline Stay in the job & 39 & $50.6(39.0$ to 62.2$)$ \\
\hline Leave§ & 38 & $49.4(37.8$ to 61.0$)$ \\
\hline Satisfaction with current job & $n=77$ & \\
\hline High & 50 & 64.1 (53.2 to 75.5$)$ \\
\hline Little & 22 & $28.2(18.8$ to 40.0$)$ \\
\hline None & 5 & $6.4(2.1$ to 14.5$)$ \\
\hline \multicolumn{3}{|l|}{ Relation with current employer } \\
\hline Relation to current employer & $n=76$ & \\
\hline Family/relative & 22 & $28.9(19.1$ to 40.5$)$ \\
\hline Friend/neighbour & 18 & $23.7(14.7$ to 34.8$)$ \\
\hline Other & 36 & 47.4 (35.8 to 59.2$)$ \\
\hline Employer's reaction to absence from work & $n=76$ & \\
\hline Penalty" & 26 & $34.2(23.7$ to 46.0$)$ \\
\hline Nothing & 50 & 65.8 (54.0 to 76.3 ) \\
\hline Physical or verbal abuse by employer & $\mathrm{n}=77$ & \\
\hline Always & 9 & $11.7(5.5$ to 21.0$)$ \\
\hline Sometimes & 24 & $31.2(21.1$ to 42.7$)$ \\
\hline 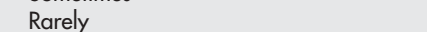 & 10 & $13.0(6.4$ to 22.6$)$ \\
\hline Never & 34 & $44.2(32.8$ to 55.9$)$ \\
\hline \multicolumn{3}{|c|}{$\begin{array}{l}\text { *Carpentry included furniture painting, mechanics included soldering radiators, metal works included autobody } \\
\text { repair, and other included workplaces of less industrial nature (electric work, hairdressing, butchery). } \\
\text { †1 US dollar }=1500 \text { Lebanese pounds; minimum wage about } 70000 \text { Lebanese pounds per week. } \\
\text { †Rent, food, education. } \\
\text { \$Prefers another job }(n=11) \text {, back to school }(n=11) \text {, travel }(n=11) \text {, combinations }(n=5) \text {. } \\
\text { - Deduction from salary }(n=11) \text {, physical or verbal abuse }(n=11) \text {, or both. }\end{array}$} \\
\hline
\end{tabular}

and nutritional habits, self-reported health complaints, use of health services, physical examination findings, blood results, and mental health scores were then compared to those of the comparison group. Statistical significance, set at a $p$ value of 0.05 , was tested using $\chi^{2}$ analysis for categorical variables and $t$ test for continuous variables. To reduce multiple comparisons, an index of health complaints was created for each body system or organ (for example, skin, eye, respiratory, musculoskeletal). A positive response to one question or more related to complaints in the system or organ was considered a positive complaint for that system or organ.
Multivariate logistic and linear regression analyses were performed to estimate the strength of association between work status (independent variable) and different health outcomes (dependent variables). Age adjusted prevalence odds ratio (OR) with $95 \%$ confidence intervals (CI) and $\beta$ coefficients were computed for the logistic and linear regression models, respectively. Associations were further adjusted for years at school, education of father and mother (illiterate, elementary, more than elementary), and occupation of father (white collar, skilled blue collar, unskilled blue collar).

Eighteen full-time school children reported working a few hours a week and four were recently re-enrolled in school 
Table 2 Sociodemographic characteristics of working children $(n=78)$ and their comparison group $(n=60)$

\begin{tabular}{|c|c|c|c|c|c|}
\hline & \multicolumn{2}{|c|}{ Working children } & \multicolumn{2}{|l|}{ Comparison } & \multirow[b]{2}{*}{$\mathrm{p}$ value } \\
\hline & n & $\%$ & $n$ & $\%$ & \\
\hline Age (years) & $n=78$ & & $n=60$ & & \\
\hline $10-12$ & 16 & 20.5 & 28 & 46.7 & \\
\hline $13-14$ & 28 & 35.9 & 17 & 28.3 & \\
\hline $15-18$ & 34 & 43.6 & 15 & 25.0 & 0.004 \\
\hline Mean (SD) & $14.09(1.76)$ & & $13.08(2.07)$ & & 0.002 \\
\hline No. of times displaced during war* & $n=78$ & & $\mathrm{n}=57$ & & \\
\hline 0 & 41 & 52.6 & 44 & 77.2 & \\
\hline 1 & 20 & 25.6 & 6 & 10.5 & \\
\hline$>1$ & 17 & 21.8 & 7 & 12.3 & 0.01 \\
\hline Mean (SD) & $0.82(1.13)$ & & $0.44(0.98)$ & & 0.04 \\
\hline Years at school & $\mathrm{n}=76$ & & $\mathrm{n}=54$ & & \\
\hline Mean (SD) & $6.49(2.69)$ & & $7.28(3.84)$ & & 0.17 \\
\hline Father's education & $\mathrm{n}=77$ & & $\mathrm{n}=58$ & & \\
\hline Illiterate & 24 & 31.2 & 7 & 12.1 & \\
\hline Elementary/reads and writes & 40 & 51.9 & 23 & 39.7 & \\
\hline$>$ Elementary & 13 & 16.9 & 28 & 48.3 & 0.001 \\
\hline Mother's education & $n=78$ & & $n=59$ & & \\
\hline Illiterate & 29 & 39.7 & 10 & 16.9 & \\
\hline Elementary/reads and writes & 32 & 33.8 & 25 & 42.3 & \\
\hline$>$ Elementary & 12 & 16.4 & 24 & 40.7 & 0.002 \\
\hline Father's occupation & $n=76$ & & $n=60$ & & \\
\hline White collar & 12 & 15.8 & 19 & 31.7 & \\
\hline Skilled blue collar & 20 & 26.3 & 18 & 30.0 & \\
\hline Unskilled blue collar & 36 & 47.4 & 13 & 21.7 & \\
\hline Military & 2 & 2.6 & 7 & 11.7 & \\
\hline Unemployed & 6 & 7.9 & 3 & 5.0 & 0.006 \\
\hline Mother involved in paid work & $n=73$ & & $\mathrm{n}=57$ & & \\
\hline Yes & 10 & 13.7 & 8 & 14.0 & \\
\hline No & 63 & 86.3 & 49 & 86.0 & 0.96 \\
\hline No. of siblings in same household & $n=78$ & & $n=60$ & & \\
\hline$<3<0$ & 22 & 28.2 & 24 & 40.0 & \\
\hline $3-5$ & 28 & 35.9 & 22 & 36.7 & \\
\hline$>5$ & 28 & 35.9 & 14 & 23.3 & 0.20 \\
\hline Proportion of working siblings (\%) & $n=76$ & & $\mathrm{n}=58$ & & \\
\hline 0 & 12 & 15.8 & 27 & 46.6 & \\
\hline$<50$ & 28 & 36.8 & 13 & 22.4 & \\
\hline$\geqslant 50$ & 36 & 47.4 & 18 & 31.0 & 0.001 \\
\hline
\end{tabular}

after some interruption. Hence, the above analysis was repeated limiting the comparison group to full-time students who never worked or stopped school. The findings were not different, so we elected to present the more diverse comparison group to ensure a bigger sample size. SPSS for Windows was used for data entry and analysis.

\section{RESULTS}

\section{Status at work}

Table 1 describes the work characteristics of the working children. Although more than $56 \%$ had been working for two or more years, $80 \%$ were still receiving less than half the minimum wage of about US\$50 (equivalent to 70000 Lebanese pounds) per week. The salary was mostly used to meet the family's basic needs like house rent, food, or education. Interestingly, two thirds of the children reported high satisfaction with their jobs, yet $50 \%$ preferred to leave to another job or back to school. One third reported being punished or penalised for absence, and $42 \%$ reported frequent verbal or physical abuse by the employer.

\section{Sociodemographic characteristics and habits}

Working children were older in age and more frequently displaced during the civil war (1975-90) than the comparison group (table 2). Their parents were of lower education, their fathers more likely to be in unskilled blue collar jobs, and a high proportion of their siblings were already enrolled in the labour force.

When nutritional and social habits were compared, working children were found to have a lower daily intake of fruit and vegetables and a higher intake of coffee and sodas (table 3). A higher proportion of working children was currently smoking or had already started dating girls.

\section{Physical health}

Working children tended to report more health complaints in general, but only a few were statistically significant after adjusting for age and social background (table 4). Working children reported skin (95\% CI 1.34 to 8.97 ), eye (95\% CI 1.08 to 6.35 ), and ear ( $95 \%$ CI 1.17 to 8.56 ) complaints within the last two weeks two to three times more frequently than nonworking children. No differences were detected in the reporting of chronic illnesses or use of health services. However, working children were almost four times (95\% CI 1.50 to 8.85 ) more exposed to injuries in the last 12 months. Close to half $(47 \%)$ of the injured working children were injured at work, and 13 of them had two or more injuries. A total of 30 work injuries were reported. The top causes were sharp objects $(n=10)$, falls $(n=7)$, and flames or hot objects $(n=6)$, mostly leading to cuts $(n=13)$ and burns $(n=8)$. Half of the children injured at work reported days off work.

Table 5 compares the clinical and laboratory findings of the two groups of children. Skin and nail changes were detected at least seven times more among working children compared to the comparison group. In addition, working children had a higher mean blood lead concentration $(13.5 \mu \mathrm{g} / \mathrm{dl} v$ $10.2 \mu \mathrm{g} / \mathrm{dl})$, with a smaller proportion $(21 \% v 53 \%)$ below the permissible level of $10 \mu \mathrm{g} / \mathrm{dl}$.

\section{Mental health}

No differences between the two groups of children were noted regarding anxiety, hopelessness, and self-esteem, or 
Table 3 Social and nutritional habits of working children $(n=78)$ and their comparison group $(n=60)$

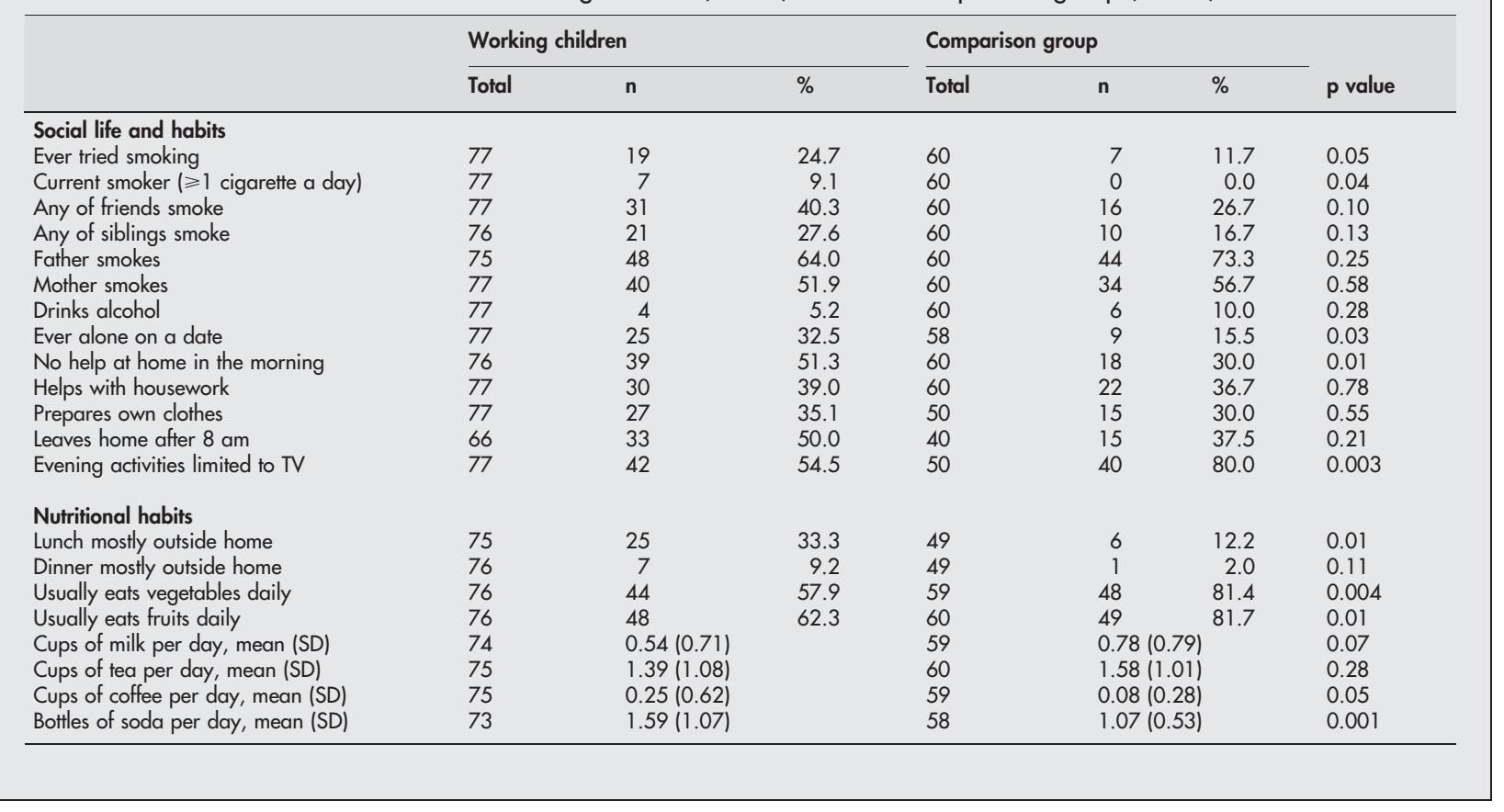

within the subcategories of the anxiety scale. The lie score was high in both $(6.67 v 6.68)$. With regard to the drawings, working children drew themselves outside the house four times more frequently than the comparison group (adjusted OR $4.50,95 \%$ CI 1.43 to 14.29 ). No differences between the two groups were noted in the complexity or general impression of the drawings. However, both groups of children were behind in their developmental age as reflected by the draw a person scale, with a greater deficit between the chronological and developmental ages for the working children (deficit of $8.0 \vee 6.5$ years, $\mathrm{p}=0.001$ ).

When asked about their future perspectives and aspirations, close to $40 \%$ of both groups of children expected to travel when they grew older. Working children foresaw themselves working in a blue collar job 4.5 times more than their comparison peers, and were more confident in attaining such a job later (adjusted OR 5.92).

\section{DISCUSSION}

The current study epitomises the challenges faced when the impact of work on the health of working children is examined. The results suggest that the health of children working in small industrial shops, in comparison to nonworking children, is disadvantaged in key physical, mental, and social aspects. Although not striking, these findings are alarming when put in perspective. The exposure of working children to work is limited to a few years, which might be too short to show health effects. Moreover, both working and comparison non-working children come from similarly poor and disadvantaged communities, which dilutes differences

\begin{tabular}{|c|c|c|c|c|c|c|}
\hline & \multicolumn{2}{|c|}{ Working children } & \multicolumn{2}{|c|}{ Comparison group } & \multirow{2}{*}{$\begin{array}{l}\text { Age adjusted }{ }^{*} \text { OR } \\
(95 \% \mathrm{Cl})\end{array}$} & \multirow{2}{*}{$\begin{array}{l}\text { Fully adjusted* OR } \\
(95 \% \mathrm{CI})\end{array}$} \\
\hline & Total & n (\%) & Total & n (\%) & & \\
\hline \multicolumn{7}{|l|}{ Recent complaints (last 2 weeks) } \\
\hline Any skin complaints & 77 & $34(44.2)$ & 60 & $14(23.3)$ & $2.82(1.29$ to 6.17$)$ & 3.50 (1.15 to 10.65$)$ \\
\hline Any eye complaints & 77 & $35(45.5)$ & 60 & $17(28.3)$ & $2.50(1.16$ to 5.37$)$ & 1.91 (0.72 to 5.04$)$ \\
\hline Any ear complaints & 77 & $27(35.1)$ & 60 & $9(15.0)$ & $3.38(1.39$ to 8.21$)$ & 3.07 (1.07 to 8.85$)$ \\
\hline Any dizziness & 77 & $31(40.3)$ & 60 & $23(38.3)$ & $0.94(0.46$ to 1.93$)$ & $1.13(0.44$ to 2.93$)$ \\
\hline Any headache & 77 & 40 (51.9) & 60 & $21(35.0)$ & 2.08 (1.01 to 4.27$)$ & 1.67 (0.68 to 4.17$)$ \\
\hline Any respiratory complaints & 77 & $38(49.4)$ & 60 & $34(56.7)$ & 1.05 (0.50 to 6.29$)$ & $1.23(0.47$ to 3.23$)$ \\
\hline Any heart palpitations & 77 & $9(11.7)$ & 60 & $4(6.7)$ & $1.78(0.50$ to 6.29$)$ & $2.60(0.43$ to 15.63$)$ \\
\hline Any gastrointestinal complaints & 76 & $28(36.8)$ & 60 & $17(28.3)$ & $2.14(0.96$ to 4.81$)$ & 1.72 (0.62 to 4.72$)$ \\
\hline Any musculoskeletal complaints & 77 & 40 (51.9) & 60 & $16(26.7)$ & 3.05 (1.43 to 6.47$)$ & 2.81 (1.08 to 7.32$)$ \\
\hline \multicolumn{7}{|l|}{ Chronic illness } \\
\hline Any history of a chronic illness & 77 & $13(16.9)$ & 60 & $6(10.0)$ & $1.48(0.51$ to 4.27$)$ & 0.65 (0.15 to 2.82$)$ \\
\hline \multicolumn{7}{|l|}{ Health during last 12 months } \\
\hline Any injury & 77 & $47(61.0)$ & 60 & $20(33.3)$ & 2.78 (1.34 to 5.71$)$ & 3.98 (1.49 to 10.64$)$ \\
\hline Any visits to doctor & 77 & $49(63.6)$ & 60 & $36(60.0)$ & 1.02 (0.49 to 2.86$)$ & 0.92 (0.35 to 2.43 ) \\
\hline Any visits to emergency services & 77 & $14(18.2)$ & 60 & $7(11.9)$ & 1.58 (0.58 to 4.33$)$ & 2.20 (0.55 to 8.77$)$ \\
\hline Any hospital admissions & 77 & $18(23.4)$ & 59 & $9(15.3)$ & 1.61 (0.65 to 2.17$)$ & $1.57(0.46$ to 5.29$)$ \\
\hline
\end{tabular}

$\mathrm{OR}$, odds ratio; $\mathrm{Cl}$, confidence interval.

*OR (logistic regression) adjusted for age, or adjusted for age, years at school, education of father, education of mother, and occupation of father. 
between the two groups. The inclusion of a second comparison group of schoolchildren from a better off neighbourhood could have helped distinguish specific work effects from non-specific socioeconomic status effects on health.

\section{Physical health}

Working children reported more acute health complaints in general, and skin, ear, and musculoskeletal complaints in particular. These complaints could be associated with their jobs, which required handling of chemicals and assuming awkward postures. Musculoskeletal complaints were also reported among children working in agriculture, ${ }^{19}{ }^{20}$ retail shops ${ }^{21}$ or small industry. ${ }^{22}{ }^{23}$ The difference in complaints between the working and comparison groups, however, was not striking; a finding that concurs with a field investigation of 78 working children (49 boys) and 103 schoolchildren (60 boys), 10-14 years of age in Cairo. ${ }^{4}$ No statistically significant differences were reported between the two groups regarding fever, diarrhoea, cough, and difficulty breathing in the past two weeks, nor in the presence of a rash or skin condition, low back pain, muscle or joint pain, or eye infection or injury in the past year. ${ }^{4}$

The physical examination of working children, also reported by Graitcer and Lerer, ${ }^{4}$ documented an increased discoloration of skin and deformities of nails; both easily linked to unprotected handling of tools and chemicals, especially solvents. Musculoskeletal symptoms, eye irritation, and tinnitus are subjective complaints that are usually difficult to confirm clinically and hence differences between the groups may not be noted.

Nutritionally, the non-working group reported a higher consumption of vegetables, fruit, and milk compared to a higher consumption of caffeine in the working group. However, the distribution of haemoglobin and iron content was similar in both groups. Likewise, the height, weight, and body mass index, after adjusting for age, were comparable between the two groups, possibly because they have similar social and nutritional backgrounds. Graitcer and Lerer ${ }^{4}$ and Mitra $^{22}$ found similar results; however, studies from Jordan reported stunting and wasting among the working children in comparison to non-working children ${ }^{24}$ and siblings, ${ }^{25}$ and increased anaemia among working children in comparison to their siblings. ${ }^{25}$

Increased $\mathrm{Pb}-\mathrm{B}$ among working children, especially among those working in mechanics shops, confirms the findings of an earlier study that compared the $\mathrm{Pb}-\mathrm{B}$ of adult blue collar to white collar workers in Beirut. ${ }^{26}$ Increased $\mathrm{Pb}-\mathrm{B}$ might be associated with exposure to lead from exhaust emissions since more than $90 \%$ of the vehicle fleet in Lebanon was operating on leaded gasoline at the time of the study. Moreover, workers in small industrial shops are in the habit of washing their greasy hands with gasoline and of eating at the workplace.

The higher occurrence of injuries among working children is consistent with the literature, regardless of the economic sector of child labour. ${ }^{27-30}$ This is attributed to lack of experience and incompatibility of the physical strength and measurements of the child with the used tools and performed tasks. A population based survey in Massachusetts reported that $24 \%$ of all adolescent injuries occurred at work. ${ }^{31}$ It is worth mentioning that working children in our study sustained many injuries on the roadways. We did not inquire whether this occurred while on duty, but it suggests that those children spent a lot of time on the street.

\section{Social health}

Work provides children with a sense of independence and an opportunity to spend long hours outside home. This might expose them to undesirable role models and to adverse habits such as smoking, drinking, and drug abuse, ${ }^{32}$ and endanger their ability to distinguish right from wrong. ${ }^{33}$ The current study confirms these observations, with a higher proportion of working children smoking, consuming caffeine, and dating. The latter behaviour was not investigated in depth, but its presence would place children at a higher risk for exposure to sexually transmitted diseases.

\section{Mental health}

Research on the effect of work on the mental health status of children has been controversial. Steinberg and Dornbusch ${ }^{34}$ reported that adolescents working for long hours are at higher risk for psychological distress, drug abuse, anxiety,

Table 5 Findings on physical examination and laboratory tests of working children and their comparison group

\begin{tabular}{|c|c|c|c|c|c|c|}
\hline & \multicolumn{2}{|c|}{ Working children } & \multicolumn{2}{|c|}{ Comparison group } & \multirow{2}{*}{$\begin{array}{l}\text { Age adjusted* OR } \\
(95 \% \mathrm{Cl}) \text { or } \beta \text { (SE) }\end{array}$} & \multirow{2}{*}{$\begin{array}{l}\text { Fully adjusted* OR } \\
(95 \% \mathrm{CI}) \text { or } \beta \text { (SE) }\end{array}$} \\
\hline & Total & n (\%) & Total & n (\%) & & \\
\hline \multicolumn{7}{|l|}{ Physical examination } \\
\hline Any skin problems & 78 & $57(73.1)$ & 60 & $19(31.7)$ & 7.50 (3.32 to 16.96$)$ & $5.90(2.15$ to 16.22$)$ \\
\hline Any nail problems & 78 & $47(60.3)$ & 60 & $9(15.0)$ & $8.79(3.68$ to 21.00$)$ & $6.83(2.45$ to 19.04$)$ \\
\hline Any eye problems & 78 & $39(50.0)$ & 60 & $17(28.3)$ & $2.20(1.05$ to 4.59$)$ & $1.73(0.68$ to 4.40$)$ \\
\hline Any nose/nasal problems & 78 & $9(11.5)$ & 60 & $1(1.7)$ & $6.62(0.80$ to 54.70$)$ & $1.02(0.07$ to 15.17$)$ \\
\hline Any musculoskeletal problems & 78 & $5(6.4)$ & 60 & $2(3.3)$ & $1.44(0.26$ to 8.04$)$ & $0.44(0.04$ to 4.68$)$ \\
\hline Systolic blood pressure $(\mathrm{mm} \mathrm{Hg}) \dagger$ & 66 & $113.3(13.6)$ & 53 & $108.3(11.2)$ & $\beta: 2.67(2.23), p=0.23$ & $\beta: 2.18(2.65), p=0.41$ \\
\hline Diastolic blood pressure $(\mathrm{mm} \mathrm{Hg}) \dagger$ & 66 & $68.9(8.2)$ & 53 & $66.1(9.3)$ & $\beta: 1.24(1.55), p=0.43$ & $\beta: 3.43(2.00), p=0.09$ \\
\hline Height $(\mathrm{cm}) \dagger$ & 78 & $157.5(12.3)$ & 54 & $155.3(14.2)$ & $\beta:-2.16(1.55), p=0.17$ & $\beta:-0.06(1.98), p=0.98$ \\
\hline Weight $(\mathrm{kg}) \dagger$ & 78 & $50.1(14.3)$ & 60 & $46.9(14.0)$ & $\beta:-1.06(2.09), p=0.61$ & $\beta: 2.19(2.70), p=0.42$ \\
\hline Body mass index $\left(\mathrm{kg} / \mathrm{m}^{2}\right) \dagger$ & 78 & $19.8(3.8)$ & 54 & $19.3(3.3)$ & $\beta: 0.62(0.63), p=0.80$ & $\beta: 1.00(0.85), p=0.24$ \\
\hline \multicolumn{7}{|l|}{ Laboratory findings } \\
\hline Haemoglobin $(\mathrm{g} / \mathrm{l}) \dagger$ & 77 & $130(10.8)$ & 59 & $130(12)$ & $\beta: 0.27(0.17), p=0.12$ & $\beta: 0.07(0.22), p=0.74$ \\
\hline Ferritin $(\mu \mathrm{g} / \mathrm{l}) \dagger$ & 77 & $31.3(19.6)$ & 59 & $27.5(15.0)$ & $\beta: 3.11(3.17), p=0.33$ & $\beta: 5.19(4.01), p=0.20$ \\
\hline Blood lead concentration $(\mu \mathrm{g} / \mathrm{dl}) \dagger$ & 77 & $13.5(6.1)$ & 59 & $10.2(5.0)$ & $\beta: 3.00(1.00), p=0.003$ & $\beta: 3.46(1.29), p=0.008$ \\
\hline Blood lead concentration $(\mu \mathrm{g} / \mathrm{dl})$ & 71 & & 53 & & & \\
\hline$<10$ & & $15(21.1)$ & & $28(52.8)$ & 1.00 (Reference) & 1.00 (Reference) \\
\hline $10-14$ & & $34(47.9)$ & & $18(34.0)$ & $3.39(1.40$ to 8.21$)$ & $2.34(0.74$ to 7.36$)$ \\
\hline $15-19$ & & 13 (18.3) & & $3(5.7)$ & $7.16(1.72$ to 29.74$)$ & $6.19(0.75$ to 51.15$)$ \\
\hline$\geqslant 20$ & & $9(12.7)$ & & $4(7.5)$ & $3.68(0.95$ to 14.31$)$ & $10.08(1.31$ to 77.39$)$ \\
\hline \multicolumn{7}{|c|}{$\begin{array}{l}\text { OR, odds ratio; } \mathrm{Cl} \text {, confidence interval; } \mathrm{SE} \text {, standard error. } \\
{ }^{*} \mathrm{OR} \text { (logistic regression) and } \beta \text { coefficient (linear regression) adjusted for age, or adjusted for age, years at school, education of father, education of mother, an } \\
\text { occupation of father. } \\
\text { †Mean (standard deviation). }\end{array}$} \\
\hline
\end{tabular}


Table 6 Mental and social health of working children and their comparison group

\begin{tabular}{|c|c|c|c|c|}
\hline & $\begin{array}{l}\text { Working children } \\
\text { n (\%) }\end{array}$ & $\begin{array}{l}\text { Comparison group } \\
\text { n (\%) }\end{array}$ & $\begin{array}{l}\text { Age education adjusted* OR } \\
(95 \% \mathrm{Cl} \text { ) or } \beta \text { (SE) }\end{array}$ & $\begin{array}{l}\text { Fully adjusted* OR } \\
(95 \% \mathrm{Cl}) \text { or } \beta \text { (SE) }\end{array}$ \\
\hline \multicolumn{5}{|l|}{ Scales } \\
\hline \multicolumn{5}{|c|}{ Anxiety score (in quartiles) } \\
\hline$\leqslant 8$ & $20(26.7)$ & 18 (38.3) & 1.00 (Reference) & 1.00 (Reference) \\
\hline $8-12$ & $16(21.3)$ & $9(19.1)$ & $1.79(0.52$ to 6.14$)$ & $1.75(0.41$ to 7.49$)$ \\
\hline $13-17$ & $20(26.7)$ & $13(27.7)$ & $1.32(0.42$ to 4.18$)$ & $1.00(0.23$ to 4.40$)$ \\
\hline$\geqslant 18$ & $19(25.3)$ & $7(14.9)$ & $2.67(1.02$ to 10.63$)$ & $0.76(0.08$ to 7.03$)$ \\
\hline Mean (SD) & $12.9(5.8)$ & $11.5(5.5)$ & $\beta: 0.50(1.15), p=0.66$ & $\beta:-0.64(1.19), p=0.60$ \\
\hline \multicolumn{5}{|c|}{ Hopelessness score (in quartiles) } \\
\hline$\leqslant 3.5$ & $17(25.0)$ & $12(24.5)$ & 1.00 (Reference) & 1.00 (Reference) \\
\hline $3.6-6.0$ & $22(32.4)$ & $17(34.7)$ & $0.71(0.23$ to 2.13$)$ & $0.38(0.09$ to 1.65$)$ \\
\hline $6.1-8.0$ & $14(20.6)$ & $14(28.6)$ & $0.88(0.23$ to 3.41$)$ & $0.56(0.09$ to 3.50$)$ \\
\hline$>8.0$ & $15(22.1)$ & $6(12.2)$ & $0.53(0.10$ to 2.77$)$ & $0.33(0.05$ to 2.48$)$ \\
\hline Mean (SD) & $6.1(3.0)$ & $5.6(2.8)$ & $\beta: 0.06(0.63), p=0.91$ & $\beta:-0.06(0.73), p=0.93$ \\
\hline \multicolumn{5}{|c|}{ Self-esteem score (in quartiles) } \\
\hline$\leqslant 14$ & $16(23.5)$ & $7(14.0)$ & $1.30(0.32$ to 5.38$)$ & $1.18(0.26$ to 5.40$)$ \\
\hline $15-17$ & $15(22.1)$ & $13(26.0)$ & $0.60(0.16$ to 2.27$)$ & $0.46(0.10$ to 2.15$)$ \\
\hline $18-20$ & $22(32.4)$ & $14(28.0)$ & $1.05(0.28$ to 3.92$)$ & $1.01(0.21$ to 4.93$)$ \\
\hline$>20$ & $15(22.1)$ & $16(32.0)$ & 1.00 (Reference) & 1.00 (Reference) \\
\hline Mean (SD) & $17.5(4.1)$ & $18.5(3.9)$ & $\beta: 0.04(0.85), p=0.97$ & $\beta: 0.48(0.88), p=0.59$ \\
\hline \multicolumn{5}{|l|}{ Child's drawing } \\
\hline \multicolumn{5}{|c|}{ Richness (complexity) of drawing } \\
\hline Low & $51(68.0)$ & $24(51.1)$ & 1.00 (Reference) & 1.00 (Reference) \\
\hline Average/high & $12(16.0)$ & $13(27.7)$ & $0.60(0.25$ to 1.42$)$ & $0.98(0.17$ to 2.76$)$ \\
\hline \multicolumn{5}{|c|}{ Child drew himself inside house } \\
\hline Yes & $41(53.9)$ & $42(77.8)$ & 1.00 (Reference) & 1.00 (Reference) \\
\hline No & $35(46.1)$ & $12(22.2)$ & 4.20 (1.61 to 10.99$)$ & 4.50 (1.43 to 14.29$)$ \\
\hline \multicolumn{5}{|l|}{ General impression } \\
\hline Negative & $55(71.4)$ & $39(67.2)$ & 1.00 (Reference) & 1.00 (Reference) \\
\hline Average/positive & $22(28.6)$ & $19(32.8)$ & 0.81 (0.35 to 1.85$)$ & $0.58(0.21$ to 1.62$)$ \\
\hline \multicolumn{5}{|c|}{ Loss in mental development (years) $\dagger$} \\
\hline Mean (SD) & $8.0(2.1)$ & $6.5(2.1)$ & B: $1.68(0.37) \neq, p=0.001$ & B: $1.72(0.43) \S, p=0.001$ \\
\hline \multicolumn{5}{|l|}{$\begin{array}{l}\text { Future dreams } \\
\text { Job when adult }\end{array}$} \\
\hline White collar & $8(10.5)$ & $24(40.7)$ & 1.00 (Reference) & 1.00 (Reference) \\
\hline Blue collar & $68(89.5)$ & $35(59.3)$ & $6.02(2.11$ to 17.20$)$ & $4.53(1.33$ to 15.48$)$ \\
\hline \multicolumn{5}{|c|}{ Confidence in attaining job } \\
\hline Not sure & $16(21.3)$ & $26(45.6)$ & 1.00 (Reference) & 1.00 (Reference) \\
\hline Sure & $59(78.7)$ & $31(54.4)$ & $3.85(1.60$ to 9.26$)$ & $5.92(2.06$ to 16.95$)$ \\
\hline \multicolumn{5}{|c|}{ Expects to travel for work } \\
\hline No & $46(60.5)$ & $35(61.4)$ & 1.00 (Reference) & 1.00 (Reference) \\
\hline Yes & $30(39.5)$ & $22(38.6)$ & $0.65(0.28$ to 1.53$)$ & $0.94(0.35$ to 2.51$)$ \\
\hline \multicolumn{5}{|c|}{$\begin{array}{l}\text { OR, odds ratio; } \mathrm{Cl} \text {, confidence interval; } \mathrm{SD} \text {, standard deviation; } \mathrm{SE} \text {, standard error. } \\
\text { *OR (logistic regression) and } \beta \text { coefficient (linear regression) adjusted for age and years at school, or adjusted for age, years at school, education of father, } \\
\text { education of mother, and occupation of father; except for loss in mental development. } \\
\text { †Loss = chronological age - mental age. } \\
\text { †Adjusted only for years at school. } \\
\text { §Adjusted for years at school, education of father, education of mother, and occupation of father. }\end{array}$} \\
\hline
\end{tabular}

depression, fatigue, and insomnia. Delinquency, antisocial behaviour, reduced self-esteem, poor group relationships, poor work orientation, and autonomy from parents were also mentioned as developmental long term costs of early employment. ${ }^{35}$ In contrast, many argue for the potential benefit of early work. Work can enhance the development of a sense of responsibility and discipline, help in the acquisition of new skills, and provide opportunity to explore new career goals and achieve economic advances. ${ }^{36}$ It may also teach the child the value of money and provide him/her with valuable role models. ${ }^{37}$

The working children in our study function in a more challenged social context. For these children, work is neither an option nor a luxury. Instead, they are forced by a poor educational system and hard living needs into exploitative work environments where they could be abused. ${ }^{33} 38$ Our working children were paid much less than the minimal legal wage and $42 \%$ reported frequent physical or verbal abuse. More than one third reported dissatisfaction with their jobs and almost 50\% preferred to leave. Consequently, we expected that working children would report higher anxiety, more hopelessness, and lower self-esteem than non-working children.
This assumption was not supported by the study findings, where no differences were observed on any of the three scales. However, interesting observations were noted when children were asked to draw themselves at home. A greater number of working children drew themselves outside the house, possibly revealing a feeling of not belonging, and they had wider developmental deficit. Nevertheless, both groups of children drew poor pictures with minimal numbers of elements and exhibited a considerable loss in mental development. This shows that all children, working or non-working, were quite disadvantaged and that schoolchildren were not particularly benefiting from being at school. Schools in poor neighbourhoods are poorly staffed and budgeted, with a high dropout rate. In other words, many of these schoolchildren may perceive themselves as temporary students and expect to join the labour force at any time. Interestingly, 59.3\% of the non-working children foresaw themselves in a blue collar job in the future. This concurs with earlier research in India ${ }^{39}$ and Latin America. ${ }^{38}$ Schools meant boredom for many children, ${ }^{39}$ and the traditional orientation of the educational system assigned them to an inferior social position. ${ }^{38}$ Consequently, children were ready to leave school and go to work ${ }^{39}$ where 
they develop an independent image of themselves as "protoadults". ${ }^{38}$ In view of an irrelevant and oppressive education, working children feel needed, useful, and contributing to their families. ${ }^{40}$

Another explanation for the lack of difference on any of the mental health scales might be the limitations in the instruments or response sets among subjects. Perrin and Last, ${ }^{41}$ for example, state that boys tend to under-report internalised symptoms of anxiety. This was reflected in the high score on the lie items within the anxiety scale for both groups, indicating a high level of defensiveness. ${ }^{13}$

\section{Study conclusions and limitations}

While working children performed worse than the comparison group on several physical, social, and mental health parameters, the differences were less than expected. If true, this finding could probably be related to the short period of exposure of working children to hazards at work and the delay in the onset of many health problems for years after exposure. Several methodological issues related to the crosssectional study design, sample size, and selection of study subjects may have also diluted the differences and biased associations towards the null.

Children who are currently working in physically demanding jobs might have been selected to work there because of their good health status or could have left the job because of injury or illness (a healthy working children effect). Moreover, the study's small sample size, reflected in the reported wide confidence intervals, could have limited its power to detect differences.

Selection biases are also of concern. Almost 12\% of the working children worked in relatively less hazardous workplaces (electric work, hairdressing, butchery), while the comparison group included children who currently or previously worked a few hours a week. The study findings, however, did not change when working children were compared to the sub-sample of "pure" schoolchildren. Moreover, the comparison group was recruited on a volunteer basis with no information on the pool of schoolchildren out of which they were drawn, precluding any assessment of its representativeness. It is possible that the comparison group may have been exposed to hazards outside the workplace, such as involvement in household chores or engagement in street activities, but this was not likely in our study sample. On the contrary, this group reported less "risky" social behaviour with less outings, more time spent at home, and no difference in contribution to housework (tables 2 and 3).

In contrast, every effort was made to reduce interviewer bias and the potential to overestimate the association between work and health outcomes. Interviewers, both physicians, and the analyst of the drawings were blinded to the work status of the child. Nevertheless, it is worth noting that using logistic regression to estimate prevalence odds ratios in cross sectional studies has been reported to overestimate the true associations. ${ }^{42}$

\section{Implications}

The study findings suggest aspects of child labour that warrant intervention. The working children carry the burden of supporting their families and in return are underpaid and experience frequent physical and verbal abuse. The real challenge remains a societal commitment to protect children, control child labour, and provide children with proper education and technical training. Short of abolishing child labour in hazardous occupations, interventions could include the improvement in work environment and the relationship between the working child and the employer, the reduction of work related injuries, the provision of after-work social and educational activities, and the provision of accessible health care centres that can routinely evaluate and manage any health complaints reported by the children. The possibility of working children adopting risky social and health behaviours should be addressed through focused awareness campaigns. Further, tomorrow's school dropouts are the next groups of working children, and those should be identified early and channelled into controlled and safe technical training programmes or sites. With regard to the causal association between work and health of children, prospective studies should be conducted to allow long term observation of the health of children as soon as they join the labour force. It is possible that the ill effects of working as a child could be best measured when the child is an adult. Studies that examine early predictors of health effects, such as neurobehavioural performance, ${ }^{43}$ could also fill a gap.

\section{ACKNOWLEDGEMENTS}

UNICEF funded this study under the auspices of the Ministry of Social Affairs in Lebanon. We thank Terre des Hommes for their help in accessing the children, and Kirk Hooks for his editorial comments on an earlier version.

\section{Authors' affiliations \\ I A Nuwayhid, J Usta, M Makarem, American University of Beirut, Lebanon}

A Khudr, A El-Zein, UNICEF, Lebanon

\section{REFERENCES}

1 International Labour Office. A future without child labour. International Labour Conference 90th session. Geneva: ILO, 2002.

2 Forastieri V. Children at Work: Health and Safety Risks. Geneva, ILO, 1997.

3 Cooper SP, Rothstein MA. Health hazards among working children in Texas. South Med J 1995;88:550-4.

4 Graitcer PL, Lerer LB. The impact of child labor on health: Report of a field investigation in Egypt, 2000. www.worldbank.org/children (accessed April 2002).

5 Morbidity, Mortality Weekly Report (MMWR). Work-related injuries and illnesses associated with child labor- United States, 1993. MMWR 1996;45:464-68.

6 Landrigan PJ. Child labor: a re-emergent threat. Am J Ind Med 1993;24:267-8.

7 Central Administration for Statistics (CAS), UNICEF. Status of Children in Lebanon 2000. Beirut, CAS \& UNICEF, 2002.

8 Nuwayhid IA. Occupational health in Lebanon: Overview and challenges. Int J Occup Environ Health 1995; 1:349-58.

9 Reynolds C, Richmond BO. Factor structure and construct validity of "What I Think and Feel": The Revised Children's Manifest Anxiety Scale. J Pers Assess 1979;43:281-3.

10 Reynolds CR, Richmond BO. What I think and feel: a revised measure of children's manifest anxiety. J Abnorm Child Psychol 1978;6:271-80.

11 Kazdin AE, French NH, Unis AS, et al. Hopelessness, depression, and suicidal intent among psychiatrically disturbed inpatient children. J Consul Clin Psychol 1983;51:504-10.

12 Coopersmith S. The antecedents of self-esteem. San Francisco: WH Freeman \& Co, 1967.

13 Reynolds C, Richmond BO. Revised Children's Manifest Anxiety Scale. Los Angeles: Western Psychological Services, 2000.

14 Kazdin AE, Rodgers A, Colbus D. The hopelessness scale for children: psychometric characteristics and concurrent validity. J Consult Clin Psychol 1986;54:241-5.

15 Guillon MS, Crocq MA, Bailey PE. The relationship between self-esteem and psychiatric disorders in adolescents. Eur Psychiatry 2003;18:59-62.

16 Lewis M, Osofsky J, Moore MS. Coding System for Drawing of Children Exposed to Community Violence. Lovisiana: Louisiana State University Medical Center, 1994

17 Siberry GK, lannone R. In: The Harriet Lane Handbook: A Manual for Pediatric House Officers, 15th edn. St Louis: Mosby, 2000.

18 Centers for Disease Control (CDC). Preventing lead poisoning in young children: A statement by the Centers for Disease Control. DHHS report 2230. Atlanta, Centers for Disease Control, US Department of Health and Human Services, 1991.

19 Bartels S, Niederman B, Waters TR. Job hazards for musculoskeletal disorders for youth working on farms. J Agric Saf Health 2000;6:191-201.

20 Wilk VA. Health hazards to children in agriculture. Am J Ind Med 1993;24:283-90.

21 Zakocs RC, Runyan CW, Schulman MD, et al. Improving safety for teens working in the retail trade sector: opportunities and obstacles. Am J Ind Med 1998;34:342-50.

22 Mitra S. A study of the health conditions of child workers in a small scale leather industry in Calcutta. Br J Ind Med 1993;50:938-40. 
23 Das PK, Shukla KP, Ory FG. An occupational health programme for adults and children in the carpet weaving industry, Mirzapur, India: a case study in the informal sector. Soc Sci Med 1992;35:1293-302.

24 Hawamdeh $\mathbf{H}$, Spencer $\mathrm{N}$. The effects of work on the growth of Jordanian boys. Child Care Health Dev 2003;29:167-72.

25 Hawamdeh H, Spencer N. Growth of working boys in Jordan: a crosssectional survey using non-working male siblings as comparisons. Child Care Health Dev 2002;28:47-9.

26 Nuwayhid I, McPhaul K, Bu-Khuzam R, et al. Determinants of elevated blood lead levels among working men in Greater Beirut. J Med Liban 2001;49:132-9.

27 Schulman MD, Evensen CT, Runyan CW, et al. Farm work is dangerous for teens: agricultural hazards and injuries among North Carolina teens. J Rural Health 1997:13:295-305.

28 Mandryk J, Harrison J. Work-related deaths of children and adolescents in Australia, 1982 to 1984. Aust J Public Health 1995; 19:46-9.

29 Suruda AJ. Injuries to working children. West J Med 1994;161:62-3.

30 Castillo DN, Landen DD, Layne La. Occupational injury deaths of 16 and 17 year olds in the United States. Am J Public Health 1994;84:646-9.

31 Brooks DR, Davis LK, Gallagher SS. Work-related injuries among Massachusetts children: a study based on emergency department data. Am J Ind Med 1993;24:313-24.

32 Greenberg E, Steinberg LD, Vaix A. Adolescents who work: work and behavioral consequences of job stress. Dev Psychol 1981;17:691-703.
33 UNICEF The State of the World's Children 1997. New York: Oxford University Press, 1997

34 Steinberg L, Dornbusch SM. Negative correlates of part time employment during adolescence: replication and elaboration. Dev Psychol 1991;27:304-13

35 Kinney JA. Health hazards to children in the service industries. Am J Ind Med 1993;24:291-300.

36 Dunn KA, Runyan CW. Deaths at work among children and adolescents. Am J Dis Child 1993;147:1044-7.

37 Committee on Environmental Health, American Academy of Pediatrics. The Hazards of Child Labor. Pediatrics 1995;95:311-13.

38 Salazar MC. Young workers in Latin America: protection or self determination. Child Welfare 1991;70:269-83.

39 Kolkere N. Our story, Our dreams: Micro and Macro Influences on Child Labor. The Urban Childhood conference: Trondheim, 1997.

40 Bequele A, Myers WE. First things first in child labor: Eliminating work detrimental to children. Geneva: ILO/UNICEF, 1995.

41 Perrin S, Last C. Do childhood anxiety measures measure anxiety? J Abnorm Child Psychol 1992;20:567-78.

42 Zocchetti C, Consonni D, Bertazzi PA. Relationship between prevalence rate ratios and odds ratios in cross-sectional studies. Int J Epidemiol 1997;26:220-3.

43 Saddik B, Nuwayhid I, Williamson A, et al. Evidence of neurotoxicity in working children in Lebanon. Neurotoxicology 2003;24:733-9.

Answers to multiple choice questions on Retirement on grounds of ill health by M Stattin, on pages 135-140

(1) b; (2) c; (3) a; (4) a; (5) d 